\title{
The role of analogy in language change \\ Supporting constructions
}

Hendrik De Smet and Olga Fischer

(KU Leuven / University of Amsterdam/ACLC)

\section{Introduction}

It is clear from the literature on language variation and change that analogy ${ }^{1}$ is difficult to capture in fixed rules, laws or principles, even though attempts have been made by, among others, Kuryłowicz (1949) and Mańczak (1958). For this reason, analogy has not been prominent as an explanatory factor in generative diachronic studies. More recently, with the rise of usage-based (e.g. Tomasello 2003, Bybee 2010), construction-grammar [CxG] (e.g. Croft 2001, Goldberg 1995, 2006), and probabilistic linguistic approaches (e.g. Bod et al. 2003, Bod 2009), the interest in the role of analogy in linguistic change -- already quite strongly present in linguistic studies in the nineteenth century (e.g. Paul 1886) -- has been revived. Other studies in the areas of language acquisition (e.g. Slobin, ed. 1985, Abbot-Smith \& Behrens 2006, Behrens 2009 etc.), cognitive science (e.g. work by Holyoak and Thagard 1995, Gentner et al. 2001, Gentner 2003, 2010, Hofstadter 1995), semiotics (studies on iconicity, e.g. Nöth 2001), and language evolution (e.g. Deacon 1997, 2003) have also pointed to analogical reasoning as a deep-seated cognitive principle at the heart of grammatical organization. In addition, the availability of increasingly larger diachronic corpora has enabled us to learn more about patterns' distributions and frequencies, both of which are essential in understanding analogical transfer.

Despite renewed interest, however, the elusiveness of analogy remains. For this reason, presumably, Traugott (2011) distinguishes between analogy and analogization, intended to separate analogy as (an important) 'motivation' from analogy as (a haphazard) 'mechanism'. The

\footnotetext{
${ }^{1}$ Under analogy we understand both the recognition of simple item similarity as well as relational (structural) analogy, see Behrens, but pace Felser??, this volume.
} 
distinction is deemed necessary since "much analogical thinking never results in change" (ibid. p.25). Analogization thus focuses on the results of analogical thinking.

Another attempt to mitigate the 'unruliness' of analogy is found in Bybee and Beckner (2014), who consider categorization more important than analogy. This goes against most psycholinguists' conviction that categorization itself can only be the result of analogical thinking (see e.g. Chalmers et al. 1992, Gentner 2010, Gentner et al. 2011). Bybee and Becker note, nevertheless, that "the much rarer change of analogical extension" is "not accomplished by analogical reasoning but rather by changes in existing categories" (p.506). Examining "a wide range of changes that have been called "analogical", they find that "all [changes] fall under the umbrella of changes in categorisation and that a separate mechanism of change dubbed 'analogical 'is not necessary". They illustrate this with the case of the past tenses of strike and dig, for which "no proportional model $[\ldots]$ is possible" because these two verbs do not share the phonological characteristics that are deemed necessary to make the analogy. That is, they do not share "the property of ending in a velar [nasal] consonant" of the wider cling, swing class (with past tense ung), to which new members were added (sling-slung, hang-hung) (ibid.).

It seems to us that analogy is interpreted too narrowly here. Analogy not only concerns a similarity between concrete (in this case phonological) forms, and a similarity between abstract patterns (in this case verbs and their past tenses) but also local similarities in function or meaning (cf. the idea of "structural mapping" [Gentner and Namy 2006, Gentner and Smith 2012]). As Anttila (2003), Itkonen (2005) and others have made clear, and as CxG linguists emphasize, analogy always involves a combination of form and meaning. The new past tenses of strike and dig can be explained by analogy when one looks more closely at the full synchronic circumstances operating at the time of their first occurrence. When we look at it in terms of analogy, the new past could well have been supported semantically by the past tenses of cut and stick 'stab' (i.e. cut and stuck), which like strike and dig convey a cutting or stabbing movement. As to form, they share the short vowel and the plosives. Like struck, stuck and dug are attested in the OED from the sixteenth century onwards. In addition, it must be mentioned that it is quite likely that struck was an independent phonetic development (cf. Ekwall 1965, §§81, 215, Hogg 1988): the ME form was [stro:k] (from OE [a:]) but with a variant [stro:k], which with other ME [o:]sounds developed to [u:] in the Great Vowel Shift and was later shortened to $[u]>[\Lambda]$ before plosives. If this is correct, the form struck itself could have strenghened the analogy. And final- 
ly, a more general iconic principle may also have played a role, that of the 'principle of quantity'. It is noteworthy that cut, struck, dug and stuck all convey a highly telic, brief movement, which is more appropriately conveyed by a phonologically shorter form (cf. also the 'ideophonic' argument put forward in Hogg [1988], where he considers the past tense snuck in relation to dug and struck). This development shows that one need not always have a very frequent pattern for analogical extension; a local pattern, if strengthened semantically, may do the job too. ${ }^{2}$

Another example of interaction between multiple local analogies - this time affecting syntactic structure - can be observed in Dutch and involves the extension of a reflexive pronoun in verbs denoting psychological activities. The category contains verbs such as zich[REFL] herinneren 'to remember', zich[REFL] realiseren 'to realise', zich[REFL] ergeren 'to be annoyed', and has been joined quite recently by verbs such as beseffen 'to realise', irriteren 'to be irritated', which are now also used reflexively by younger speakers. The analogy here concerns not only the semantic similarity but also the fact that some of these verbs share a causative structure. Thus, there is both causative dit herinnert me[OBJ] eraan dat... / dit ergert me[OBJ] 'this reminds me that.../ this annoys me', and reflexive $i k$ herinner me[REFL] dat.../ ik erger me[REFL] eraan dat... 'I remember that ... I I am annoyed that', resulting in the causative verb irriteren (dit irriteert me[OBJ] 'this irritates me) to also develop a reflexive construction: ik irriteer me[REFL] 'I am irritated'. Thus a network of analogies, involving both causative and reflexive verbs expressing mental activities, may lead to local change.

What these examples show is that if analogy is to be properly understood, its operation must be seen against the background of complex constructional networks capturing the myriad relations between constructions. In this respect, Abbot-Smith \& Behrens (2006) propose the notion of "supporting constructions" in language acquisition, to explain how it is that, for instance, German children learn certain constructions earlier than others. In Abbot-Smith and Behrens (2006: 1019), it was found that a 'supported construction' was acquired earlier and faster than a non-supported one if the source and target constructions "share[d] lexical or morphological subparts". They show that the sein-passive (i.e. the perfect passive formed with HAVE-been+past participle in English) is acquired earlier than the werden-passive (the non-perfect passive formed with BE+past participle) due to the fact that a lexical-morphological and highly frequent subpart

\footnotetext{
${ }^{2}$ Barðdal (2008) makes clear that analogy may occur even with low type frequency provided there is strong semantic coherence.
} 
of the construction is already familiar to German children in the form of the perfect construction with sein+past participle. Interestingly, they also show that the acquisition of a target construction can be hindered if two constructions "share an identical semantic-pragmatic function".

We believe that the notion of 'supporting construction' may also help to explain how constructions spread analogically in diachrony. As we will show, the 'construction conspiracy hypothesis' - the term Abbot-Smith and Behrens use - can be extended to language change. It has been observed, for instance, that an analogical extension is the more likely, the more its outcome resembles one or more already existent patterns (Bybee \& Slobin 1981; Fischer 2011, 2015; De Smet 2012, 2013). The role of those existent patterns in language change is much like that of Abbot-Smith \& Behrens's (2006) supporting constructions. They facilitate the emergence of an innovative pattern, presumably because shared phonological, functional or syntactic components are already entrenched and give the 'innovative form' ${ }^{3}$ a selectional advantage. In language change, this has the effect of obscuring the novelty of the innovative form - a characteristic feature of change that has been pointed out by many observers before (e.g. Warner 1982; Aitchison 1991; Denison 2001 [Denison this volume]). In that light, it can be hypothesized that the likelihood of an innovation depends on the set of supporting constructions sanctioning the innovative form.

From this it follows that the course of change is highly contingent. Because every (potential) new expression has a unique set of supporting constructions, as determined by its specific form, syntax and function, the chances for an item to extend its range of use vary from item to item, and from grammatical context to grammatical context. Indeed, where the grammaticalization literature has initially revealed recurrent pathways of change (e.g. Heine \& Kuteva 2002), more recently attention has moved to the ways in which each specific grammaticalization is also uniquely conditioned by the form and function of the source item and by similarity relations to other constructions (e.g. Fischer 2007; Breban 2010; Ghesquière 2014). The 'construction conspiracy hypothesis', applied to diachrony, is well-suited to explaining the contingency of change.

To be sure, direct application of a concept from the field of language acquisition to that of language change is not completely unproblematic. There are clearly a number of differences between the data in the two fields. First, frequency in the acquisition case relates to both input

\footnotetext{
${ }^{3}$ By 'innovative form' we here mean both ontogenetically innovative (in acquisition) and phylogenetically innovative (in change).
} 
frequency of the adult and output frequency of the child. In a diachronic study we only have output frequencies (cf. the types of frequencies noted by Hilpert, this volume), but it is likely, since we are here dealing with much less limited adult language utterances and fully developed adult grammars, and a range of generations, that a distinction between input and output frequencies is less relevant.

Second, a problem in the Abbott-Smith/Behrens study was that they could only rely on the acquisition data of one child, providing homogeneous and dense data but limited to only one speaker (although the findings were supported by less dense data from three other children), while the historical data are problematic, as we mentioned above, in that they are quite (or possibly too) diverse, coming from many different sources involving many types of variation (genre, dialect, age, sex, education, social class etc.).

Third, the construction(s) that offer 'support' to a particular innovation in diachronic studies may be more numerous and may provide support of both a substantive (lexicalmorphological) as well as of a more abstract/structural and/or semantic-pragmatic type. After all, in change we are dealing with adults, rather than children. ${ }^{4}$ Adults have already acquired the full scale of constructions possible, and pay attention not only to low-level phenomena but also to high-level ones (cf. Chalmers et al. 1992), involving 'structure mapping' (cf. Gentner et al. 2011). Children, on the other hand, concentrate on substantive elements in the early years of acquisition (cf. Goldwater et al. 2011). ${ }^{5}$

Fourth, it seems also quite likely that we will not find the kind of 'speed' noticed in Abbott-Smith/Behrens because we are dealing with a very diverse number of 'speakers', constituting a mix of generations per period, and a very diverse number of genres etc. Therefore, the 'construction conspiracy' hypothesis applied to language change must primarily focus on frequency and chronological order of appearance of new patterns. Conceivably, though, there is

\footnotetext{
${ }^{4}$ As we saw above in the case of strike/struck etc. and Dutch (zich) beseffen etc., where both for$\mathrm{mal} / \mathrm{structuraland}$ functional/semantic similarities formed the 'support' for the new (analogical) structures. Behrens, this volume, notes that analogy in children's early acquisition is item-based

5 Goldwater et al. (2011) summarize this as follows: "Because the ability to map relationally complex structures develops with age, younger children are less successful than older children at mapping both semantic and syntactic relations. Consistent with this account, 4-year-old children showed priming only of semantic relations when surface similarity across utterances was limited, whereas 5-year-olds showed priming of both semantic and syntactic structure regardless of shared surface similarity. The priming of semantic structure without syntactic structure is uniquely predicted by the structure-mapping account because others have interpreted structural priming as a reflection of developing syntactic knowledge."
} 
also a difference in speed between the way more substantive analogies spread in language change compared to more abstract/structural ones.

Fifth, we also expect that there may be a difference concerning Abbott-Smith/Behrens' finding that the acquisition of the target construction can be hindered if other constructions share an identical semantic-pragmatic function. Whereas children are still in the process of learning as many constructions as possible and trying hard to make distinctions between them, i.e. they are busy extending their language and their grammar, adults are confronted with a plethora of constructions that have already been entrenched (cf. Ellis, Lieven, this volume) and they may therefore be more likely to shift relatively infrequent or new constructions towards already existent ones (or mix them up), especially when they are quite similar in form and meaning. They might be more likely to simplify the grammar where possible for the sake of economy. In addition, as already indicated above, young children are more aware still of low-level rather than high-level distinctions, thus privileging substantive forms over more abstract structural patterns, which they are still in the process of acquiring. In contrast, as adults we 'learn' to see only those substantive differences which are functional or relevant, gradually ignoring non-functional ones. In other words, we don't learn and remember more than is absolutely necessary. This is what Hawkins (2004:40) has called the principle of 'Minimize Forms':

Minimizations in unique form-property pairings are accomplished by expanding the compatibility of certain forms with a wider range of properties [meanings]. Ambiguity, vagueness, and zero specification are efficient, inasmuch as they reduce the total number of forms that are needed in a language.

Hawkins notes that this minimization is connected with the frequency of the form and/or the processing ease of assigning a particular property to a reduced form. The ambiguity that arises is no problem since "[t]he multiple properties that are assignable to a given form can generally be reduced to a specific P[roperty] in actual language use by exploiting 'context' in various ways" (ibid: 41). Thus, it seems likely that in language change, in contrast to language acquisition, 
pragmatic-semantic similarity may in fact 'support' the 'acquisition ${ }^{\prime 6}$ of a new construction out of earlier, analogically similar, source constructions.

To find out how the 'construction conspiracy hypothesis' may apply to language change, and how it may differ from the way it functions in language acquisition, we will briefly discuss two diachronic cases in the history of English, partly based on existing literature (investigated in Fischer 1994, 2015 and De Smet 2012). The changes include the development of semi-modal HAVE-to (section 2) and the development of the new degree modifier as good as, compared to that of other degree modifiers (section 3). We will also note, where appropriate, what happened to similar source constructions in other languages to find out possible differences in analogical outcome.

\section{The grammaticalization of HAVE-to}

The development of HAVE in combination with a to-infinitive has long been considered a typical case of grammaticalization following the characteristics as traditionally defined in the framework, i.e. bleaching, chunking, phonetic reduction, and generally comprising a gradual change steered semantically and by pragmatic inferencing, which is followed by a syntactic reanalysis into, in this case, a semi-auxiliary (Fleischman 1982, Brinton 1991, Heine 1993, Krug 2000, Łęcki 2010). Fischer (1994) countered the essentially semantic-pragmatic view of the development, arguing instead that a change in basic word order from SOV to SVO taking place in the course of the Middle English period played a primary role. Fischer (2015) returns to the case in order to find out to what extent analogy of both a structural and a substantive type may have been involved, and how this may have 'supported' the development of HAVE-to into a semi-auxiliary expressing necessity. The only way to ascertain the strength of this 'support' and hence its influence, is by looking at the dates and frequencies of occurrence of the support construction(s), and establishing similarities in both form and meaning with the target structure. On the basis of the Corpus of Middle English Verse and Prose, ${ }^{7}$ it can be shown that a (partly) substantive formal pattern (the adjacency of HAVE and the to-infinitive) became increasingly frequent across texts, serving as a

\footnotetext{
${ }^{6}$ We have put 'acquisition' in quotes because, as Deacon (1997) has convincingly shown, analogy is in fact a default, it concerns our inability to see a difference between two constructions due to inattention, laziness etc. (economy). This explains how innovations leading to change may sneak into the language imperceptibly. (cf. Ellis on the importance of absence of saliency)

${ }^{7}$ See http://quod.lib.umich.edu/
} 
possible analogical model for a later semi-auxiliary HAVE-to, and that other analogies of both a substantive, structural and semantic-pragmatic type may have helped to establish the later necessity meaning of the phrase. ${ }^{8}$

One of the problems with the traditional account is that there is no evidence for a gradual semantic change in the verb HAVE from 'possess' via a more general or bleached meaning to a necessity sense before to-infinitives. Problematic too is that both bleached HAVE (see (1)) and occasional necessity meanings were already present in Old English (cf. Fischer 1994), as seen in (2). (Note that in (3)-(5), the meaning cannot be one of necessity, in contrast to (2)). The new semimodal construction with a regular necessity meaning is only firmly attested from Early Modern English onwards, and not really common until the nineteenth century (Krug 2000:89-90). A general problem in grammaticalization studies is that the investigation typically concentrates only on the construction that is changing and hence on the diachronic development, and not on the constructions that may provide support, i.e. the synchronic situation current at the time (cf. Noël 2012). ${ }^{9}$

And her beoð swype genihtsume weolocas... Hit hafað eac pis land
And here are very abundant whelks... It has also this land
sealtseapas, and hit hafap hat waeter (Bede 1,026.9)
salt-springs, and it has hot water

'And there are plenty of whelks ... the country also has (or: 'there are also') salt springs and hot water'

hafst hu aceras to erigenne (ÆGram. 135.2)

have you acres to plow

'do you have acres you could/should plow? /are there acres for you to plow?' (necessity possible)

hwile $p u$ hefdest clað to werien. and to etene and to drinken $\backslash$

\footnotetext{
8 The meaning that HAVE-to develops in the course of time can best be described as 'external necessity' or, a term used by Narrog (2005), "event-oriented" necessity. According to Coates (1983) HAVE-to differs from MUST and HAVE-got-to, in that in the former "the speaker is never involved" (p. 53); "the speaker is neutral"and "never the source of obligation"(p. 56). Here we will simply use the term 'necessity' to refer to the developing meaning of HAVE-to.

${ }^{9}$ Noël (2012:5) remarks concerning Bybee's (2010:107) view on grammaticalization which is seen as "involv[ing] the creation of a new construction out of an existing construction", that it is strange, especially for a usage-based linguist, that the creation of a new construction "into an existing construction" is not considered "equally important".
} 
'while you had clothes to wear, and to eat and to drink' (necessity unlikely)

(Old English Homilies, series 1, EETS, Morris 1868:33)

Ic haebbe mete to etene pone pe ge nyton (Jn (WSCp)4.32)

I have food to eat that that you not-know

'There is food I (may/can) eat that you know nothing of/There is food for me to eat that ...' (necessity highly unlikely since Ic refers to Jezus/God)

be Sageatas selran nabban to geceosenne cyning anigne

the Seagates better [ACC] not-have to choose king any[ACC] (Beowulf 1850-51)

'The Seagates do not have any better man to choose (which they can choose) as king/ For the Seagates there wasn't a better man to choose as king' (necessity impossible)

The questions that arise with respect to this particular grammaticalization scenario then are: why were there such long time gaps between the various stages of the development (cf. Heine 1993:67: "grammaticalization is a continuous process that does not stop at a certain point"), why did HAVE-to develop a meaning of necessity rather than e.g. future (as could happen elsewhere), and why did it become a modal (semi-)auxiliary?

If grammaticalization pathways are seen as potentially universal (cf. Haspelmath 1989), and steered by deep universal cognitive mechanisms (cf. Heine 2014), ${ }^{10}$ then why did similar source constructions in other related languages containing a verb like HAVE and an infinitive not undergo a similar development? In Dutch, for instance, the same cognate construction did not become a (semi-)auxiliary nor develop a consistent sense of necessity (Fischer 1994, Van Steenis 2013), its use being pretty much as it was in Old English. One of the reasons is that Dutch did not change into a consistent SVO language like English; SOV order remained the rule in subordinate finite and non-finite clauses. This meant that a fixed structural adjacency of the finite verb and the infinitive did not develop as a support construction for a (semi-)auxiliary status of the finite verb (cf. Fischer 1994, and see below). In the Romance languages, which did become more strictly

\footnotetext{
${ }^{10}$ Heine (2014) writes in connection with the unidirectionality of grammaticalzation: "It is only the cognitive dimension that is sensitive to directionality: It accounts for the cross-linguistically regular transfer from movement in space to prediction - a transfer that can be interpreted meaningfully only in terms of an elementary metaphorical capacity recruited to bridge the gap between two contrasting domains of human conceptualization" (emphasis added).
} 
SVO, the cognates of Latin habere following an infinitive acquired future sense, which might also have been a possibility in English, cf. Yanovich (2013). ${ }^{11}$ A very interesting case is the grammaticalization of Spanish tener que/de and Portuguese ter que/de, where the possessive verb tener /ter 'to hold' did develop a meaning of necessity. In many ways the situation is similar to the one in English due to similarities in basic word order, but here too there are important differences due to the presence of other support constructions (cf. Fischer and Olbertz in prep.).

There are good reasons to assume that the developments that ultimately led to the semiauxiliary status of HAVE-to are the result of a complex of factors which are all of the 'supported' and thus synchronic kind, i.e. the changes are not driven construction-internally or unidirectionally by the process of grammaticalization itself. First, there is the increasing adjacency of HAVE and the toinfinitive already noted above, which led to their being interpreted as a chunk [for chunking, see Ellis, Bybee and Moder, and for frequency, Baayen, Ramscart, this volume]. This adjacency already emerged earlier: in constructions with preposing of the $\mathrm{NP}_{\text {ов }}$ via $w$-movement (as e.g. in (6) (cf. also Krug 2000: 98-99) or topicalization (e.g. (7)), or heavy NP shift (e.g. (8)), all quite frequent, as seen in rows 1,4 , and 5 in Table 1.

\section{Lord! what nede shulde Crist have to lepe doun pus fro pe pynacle}

$$
\text { (ME Corpus, Wyclif) }
$$

'Lord, what need should Christ have to leap down thus from the pinnacle'

... Na clathes pai salle have to gang in (ME Corpus, Pricke of Conscience)

'... No clothes they shall have to walk-about in'

(8) a. ... Pat has to stere bath se \& land. (ME Corpus, Altenglische Legenden)

'... who has to govern both sea and land'

b. And qua so will has to wete how it worthid eftir (ME Corpus, The Wars of Alexander)

'And who has [the] desire to know how it will-become afterwards'

\begin{tabular}{|l|l|l|c|}
\hline main type & Subtypes & Interpretation & (sub)total \\
\hline 1 two NP objects & preposed object + HAVE + to- inf. + object & Old interpretation only & 49 \\
\hline 2 & $\begin{array}{l}\text { HAVE }+ \text { to-inf. + object (inf) }+ \text { object } \\
\text { (have })\end{array}$ & Old interpretation only & 1 \\
\hline
\end{tabular}

\footnotetext{
11 Yanovich (p.c.) also mentioned that future sense still occurs in English but only in sentences in combination with
} yet as in: I have yet to find a solution to this problem. 


\begin{tabular}{|l|l|l|c|}
\hline 3 & object $($ inf $)+$ object $($ have $)+$ HAVE + to- inf. & Old interpretation only & 1 \\
\hline & & Subtotal & $\mathbf{5 1}$ \\
\hline 4 shared object & preposed shared object + HAVE + to- inf. & Mostly old, new possible & 74 \\
\hline 5 & HAVE + to - inf. + shared object & Mostly old, new possible & 14 \\
\hline 6 & HAVE + to- inf. + object (shared?) & Mostly old, new possible & 10 \\
\hline & & Subtotal & $\mathbf{9 8}$ \\
\hline 7 no explicit object & HAVE + to- inf. (passive, intransitive (?)) & Mostly old, new possible & $\mathbf{3 3}$ \\
\hline & & Total: with to-infinitive & $\mathbf{1 8 2}$ \\
\hline 8 other types & HAVE (as perfect or possessive) + to + NP & & 931 \\
& to $=$ too/two & & 32 \\
& hast as a form of the verb haste $(n)$ & & 13 \\
\hline
\end{tabular}

Table 1: Occurrences of have, haue, hast, has etc. followed immediately by a to-infinitive in 'The Corpus of Middle English Prose and Verse' (from Fischer 2015).

Table 1 only looks at frequencies of the adjacency of HAVE and to in Middle English. Quite clearly more corpus research making use of syntactically tagged corpora is necessary to find out how this relates to non-adjacent cases of HAVE and to in the period (cf. Hilpert, this volume on relative frequency). From Fischer (1994), which was based on all instances of HAVE and toinfinitives in the Helsinki Corpus, it was already clear that overall the use of HAVE and a toinfinitive increased in the course of the Middle English period. It is also important to note that topicalization, e.g. of the object, was much more frequent in Old and Middle English (as it still is in Dutch and German) compared to Modern English because it has an important discourse role marking 'given' from 'new' (see the studies in Meurman-Solin et al. 2012).

Second, next to this increase in adjacency, there is a steep rise in Middle English of toinfinitives as a replacement for that-clauses, so that we see more and more patterns of VPs consisting of a verb followed by a to-infinitival complement. Manabe (1989: 21) shows that the ratio of to-infinitives to pat-clauses in Old English is 20.1 per cent as against 79.9, whereas in the fourteenth century this has changed into 62.3 and 37.7 respectively, and in the fifteenth century to 72.5 and 27.5 , almost a complete reversal (ibid.:165-6). Also of interest is the fact that the greatest increase occurs after the verbs of 'Cause-Allow' (92.7 per cent of infinitives), followed by 'Command-Desire' (73.4 per cent). All the other possible categories ('Perception', 'Love-Fear', 'Teach-Help', 'Say-Declare') score much lower. The verbs that score high are much more closely connected to modality, and more likely to become auxiliary-type verbs; indeed verbs expressing 'Cause' or 'Command' are easily connected with modal necessity. It may not be surprising, therefore, that the modal to-infinitive after HAVE, which also began to 
function as a causative around this time (cf. Hollmann 2003 and see also Table 2), also followed this tendency (cf. also Los 2005).

Third, another, somewhat more abstract structural analogy that may have played a role is the already regular use in Old English of inanimate subjects with weak possessive/existential HAVE, paving the way for inanimate subjects in constructions with HAVE-to. An example of this was already given in (1). The weak semantic link that exists in such existential constructions between the subject of the clause and the object in terms of transitivity (cf. Hopper and Thompson 1980), may have played a role too, as we will see below.

Fourth, in addition to these structural analogies, more substantive types of analogical support constructions were probably also influential in the process, such as the very high frequency of the construction with the infinitive DO, with or without ${ }^{12}$ an explicit direct object of HAVE, as seen in Table 2 (cf. (9)a and (b) respectively), and the relatively frequent occurrence of the construction HAVE +nede+to-inf. (cf. 10) (see also Table 3 below). ${ }^{13}$

\begin{tabular}{|c|c|c|c|}
\hline main type & Subtypes & Interpretation & (sub)total \\
\hline 1 two NP objects & HAVE+object+(for)to-DO+object & Old interpretation only & 144 \\
\hline 2 & HAVE+object+objec +(for)to-DO & Old interpretation only & 17 \\
\hline \multirow[t]{2}{*}{3} & preposed object+HAVE+to-DO+object & Old interpretation only & 9 \\
\hline & 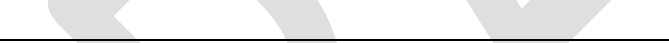 & Subtotal & 170 \\
\hline 4 shared object & HAVE + shared object + (for) to DO & Mostly old, new possible & 91 \\
\hline 5 & $\begin{array}{l}\text { preposed shared object +HAVE+(adverb) + } \\
\text { (for)to-DO }\end{array}$ & New meaning is possible & 58 \\
\hline 6 & HAVE+(for)to-DO+shared object & New meaning is possible & 13 \\
\hline & HAVE+(for)to-DO+adverb/implicit object & New meaning is possible & 2 \\
\hline & 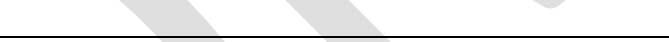 & Subtotal & 164 \\
\hline $\begin{array}{l}8 \text { 'have dealings } \\
\text { with' }\end{array}$ & $\begin{array}{l}\text { HAVE with NP (for)to-DO } \\
\text { with NP HAVE (not etc.) (for)to-DO }\end{array}$ & $\begin{array}{l}\text { Implicit object, only old } \\
\text { meaning possible }\end{array}$ & 89 \\
\hline \multirow[t]{2}{*}{9 causative HAVE } & HAVE+object +to-DO & Causative & 6 \\
\hline & & $\begin{array}{l}\text { subtotal with (for)to- } \\
\text { infinitive }\end{array}$ & 431 \\
\hline 10 other types & $\begin{array}{l}\text { HAVE (as perfect or possessive }+ \text { to }+\mathrm{NP} \\
\text { to }=\text { too/two }\end{array}$ & not applicable & 225 \\
\hline
\end{tabular}

Table 2: Occurrences of have, haue, hast, has etc (...) followed by to do(n)(e) in 'The Corpus of Middle English Prose and Verse' (from Fischer 2015) ${ }^{14}$

${ }^{12}$ Cases without an explicit object may well have prepared the way for the later use of intransitive infinitives with have to.

13 The increase in use of HAVE and need in Middle and early Modern English was already quite noticeable in the corpus investigated in Fischer 1994, giving grounds for looking at this combination in more detail.

${ }^{14} \operatorname{To} d o(n)(e)$ occurs 2976 times in the Corpus, roughly 14 per cent of these are in some combination with HAVE. It is important to note that the construction with to $d o(n)(e)$ in row 8 only provides a formal substantive analogy for the later modal necessity usage (the infinitive usually followed HAVE immediately since the 
(9) a. and I have mych to do with myn owne mat[ers] . . ( so that in good ffeyth I can nat make an end lightly) (ME Corpus, Stonor Letters)

'and I have much to do/there is much to do concerning my own business (so that in good faith I cannot finish things easily)'

b. $\quad$ and your Maystyrshepe seyde to me that ye wolde nott have to do with hytt in no wyse (ME Corpus, Stonor Letters)

'... that you would not have [any dealings/anything] to do with it in any way'

(10) a. 3if pei had nede to ride in pat contrey (ME Corpus, Three Kings of Cologne)

'if they had (a) need to ride in that country'

b. I wat pou nede has to be hale (ME Corpus, Cursor Mundi)

'I know (that) you have (a) need to be whole (e.g. bodily sound)'

The analogical pattern with nede is crucial as a support, since it answers the question where the later, strong and fixed meaning of necessity comes from if it is not seen as the result of a unidirectional, construction-internal grammaticalization process as in the traditional explanation. The other support patterns mentioned above provided only formal similarities (both of a substantive and structural kind), their semantics always being 'weakly possessive' as in the Old English period.

The influence of HAVE+nede+to-infinitive on the grammaticalization of HAVE-to has to be seen in the light of yet other constructions with need, providing further analogical support. Table 3 indicates a highly frequent co-occurrence of nede with both HAVE and an infinitive (195 instances) and with MUST nede(s) and an infinitive (227 instances). ${ }^{15}$

direct object of HAVE was mostly left implicit). Semantically, it was close to the original Old English 'weak possessive' sense; it never conveyed necessity, as is indeed still the case (as in e.g. This book has to do with the divisions within the church).

15 It is important to mention that nede was originally a noun, of which the genitive and instrumental cases (nedes and nede respectively) came to be used adverbially. It thus became impossible for the speaker to make a clear distinction between adverb (when used with must) and noun usage (when used with have). This explains the equation in the speaker's mind of must nedes with have nede to. This confusion becomes particularly clear from mixed usages as commented on below. 


\begin{tabular}{|l|l|c|}
\hline Main type & Subtypes & Totals \\
\hline HAVE+nede+inf. & (a) HAVE+nede+PP/NP+to-inf. & 9 \\
\hline & (b) HAVE+nede+(for)to-inf. & 78 \\
\hline & (c) to-inf.HAVE+nede & 54 \\
\hline & (d) HAVE+nede+NP-object & 54 \\
\hline & $\begin{array}{l}\text { (e) HAVE+nede+to-inf. OR NP-object } \\
\text { (unclear) }\end{array}$ & 7 \\
\hline MUST+nede(s)+zero inf. & Total & $\mathbf{1 9 5}$ \\
\hline & (f) mot $(e)(n)$ etc.+nede+zero $(/ t o)$ inf. & 131 \\
\hline & (g) mot(e) $(n)$ etc.+nedes+zero inf. & 96 \\
\hline impersonal BE+nede+to-inf. & Total & $\mathbf{2 2 7}$ \\
\hline & $\begin{array}{l}\text { (h) } \text { is, } \text { was, } \text { war,wer }(e)(n), \text { be nede+to- } \\
\text { inf. }\end{array}$ & $\mathbf{1 8 8}$ \\
\hline & $\begin{array}{l}\text { Total of all } \text { nede } \text { constructions with } \\
\text { inf. }\end{array}$ & $\mathbf{4 1 0}$ \\
\hline
\end{tabular}

Table 3 Occurrences with HAVE, MUST, and impersonal BE, and the noun/adverb nede $(s)$, in 'The Corpus of Middle English Prose and Verse'(from Fischer 2015). ${ }^{16}$

Similarly, the impersonal construction with BE+nede in the last row of Table 3, may also have been an influence since the empty verbs BE and HAVE are also to some extent interchangeable (as referred to above in their use in existential constructions), and, perhaps more importantly, since impersonal constructions were disappearing in the late Middle English period. This latter fact would have favoured (personal) HAVE, which takes a nominative subject for the experiencer role, over (impersonal) BE, where the experiencer, if present, is found in the dative :

That yow[DAT] were nede / to resten hastily (ME Corpus, Shipman's Tale)

All three constructions in Table 3 may well have helped the semantic change, strengthening the notion of necessity, which plays a primary role in them. The fact that MUST with the adverb nedes occurs as a kind of fixed idiom (also in the presumably mixed form MUST nede, without the genitive adverbial $-s)$ ), both strongly conveying necessity, may in turn have influenced the interpretation of the form HAVE nede, making it look like a fixed phrase with a similar modal meaning.

\footnotetext{
${ }^{16}$ Exact word order of elements in the constructions is not indicated. Only combinations with nede(s) have been counted, other spellings (neod $(e)$, need $(e))$ being rare. The form nede occurs in total 4442 times in the Corpus, of which at least 174 are verbs, leaving roughly 4268 nouns. This means that about 10 per cent of occurrences of the noun nede occur in the type of constructions collected in Table 3. Also noteworthy is that the construction with HAVE+need is rare in Old English. Only 10 examples were found in the Dictionary of Old English corpus, only one of which has an infinitive, making it likely that it was indeed replacing an impersonal construction as argued here.
} 
Interesting in this respect, too, are a few occurrences of MUST nede followed by a to-infinitive rather than the usual zero-infinitive (row (f) in Table 3). Furthermore neden also appears by itself as a verb in an impersonal construction: me nedeth/nedyth/neded etc. (+to-infinitive), next to $\mathrm{BE}$ nede, which may also have helped establish a pattern of HAVE+nede as a composite predicate (cf. Table 4 below).

As already hinted at, the impersonal verb neden disappeared, together with impersonal BE nede and other impersonal constructions in late Middle English, thus providing a kind of 'negative support'. (Or, to put it differently, the presence of impersonal neden expressing'external necessity' may have hindered the development of this sense for HAVE (nede)-to because the two expressions would have shared "an identical pragmatic-semantic function" in terms of AbbottSmith/Behrens, referred to in section 1). Overall, impersonal constructions became replaced by personal ones. In the case of me/him/her nedeth and him was need the 'replacement', i.e. the new personal form he nedeth etc. with an animate, and hence more transitive subject, ${ }^{17}$ expressed more clearly an 'internal need' on the part of the subject rather than some external need or necessity. The latter was typically the case in the impersonal construction, where the dative experiencer in the by now regular object position after the verb (due to the SOV> SVO change mentioned before) expresses an entity that is affected by external circumstances rather than one actively involved in it. This relates the impersonal structure (when accompanied by an infinitive, which is the more frequent pattern, see Table 4) more closely to necessity because when there is an external need on someone to do (infinitive) something, he, as it were, 'has to' do it.

\begin{tabular}{|l|l|c|}
\hline Main type & Subtypes & Totals \\
\hline nedeth (impersonal verb) & (a) pronoun[DATIVE]+nedeth etc.+NP-object & 173 \\
\hline & (b) full, lexical NP[DATIVE?]+nedeth+NP-object & 20 \\
\hline & (c) pronoun[DATIVE]+nedeth+(for)(to)-infinitive & 105 \\
\hline & (d) full lexical NP[DATIVE?]+nedeth+(for)(to)-infinitive & 39 \\
\hline & $\begin{array}{l}\text { (e) Prepositional NP (for/to)+nedeth }+(\text { for })(\text { to }) \text {-infinitive/NP- } \\
\text { object }\end{array}$ & 13 \\
\hline
\end{tabular}

\footnotetext{
${ }^{17}$ According to Hopper and Thompson (1980), animacy is one of the parameters that increases the overall transitivity of the clause.
} 


\begin{tabular}{|l|l|c|}
\hline & Total & $\mathbf{3 5 0}$ \\
\hline neden (personal verb) & $\begin{array}{l}\text { (f) active construction (NP[NOM] nedeth+complement (nomi- } \\
\text { nal or infinitival) }\end{array}$ & 39 \\
\hline & (g) passive construction (NP[NOM] BE neded (+to-infinitive) & 45 \\
\hline & Total & $\mathbf{8 4}$ \\
\hline
\end{tabular}

Table 4: Constructions with the (im)personal verb NEED (from Fischer 2015) ${ }^{18} 1920$

What this shows is that with the loss of this impersonal (more external) nedeth and the rise of personal (more transitive) neden, a gap arose regarding the expression of external necessity. It is quite possible that this gap was filled by the development of HAVE-to into a modal semiauxiliary of (external) necessity. This was possible because the construction with HAVE-to already allowed occasional modal interpretations connoting necessity, and it was already a frequent combination with the noun nede (followed by a to-infinitive), which was likewise tinged with necessity. Note furthermore that HAVE-to when it occurs by itself without the noun nede, loses transitivity because there is no longer a NP object present. In fact the subject of HAVE-to can now be said to be without a theta-role, as is the case with passive and existential constructions which cannot assign a theta-role to their subject. ${ }^{21}$ This weakens the involvement of the subject and hence strengthens the sense of external necessity.

Once HAVE-to became part of the modal auxiliary system, it could also develop a narrower semantic role within this closed system, in which there was no place for the looser kind of relational verb that it was before since it could no longer indicate any relation between a subject and an object, as it had before. No doubt other developments involving the core modals, in which they lost some

18 The order given in (a) (row 1) is the usual order, but the dative pronoun may also follow the verb.

${ }^{19}$ Coordinate constructions are not counted because the case of the 'subject' is not clear in this case.

${ }^{20}$ It is to be noted that the personal verb appears only in late Middle English, almost all instances in Table 4 coming from the fourteenth and fifteenth centuries. The Table does not include the impersonal constructions with empty subjects (hit/there), of which there are many (adding, by the way, to the high number of constructions with infinitives), since the (dative) experiencer is usually missing here (this construction too disappears).

${ }^{21}$ In generative linguistics, this is called 'Burzio's generalization': the observation that a verb can assign a theta (or semantic) role to its subject position if and only if it can assign an accusative case to its object. This pertains to passives and unaccusatives like the ice melted. Typical for both these categories is that the subject argument is not a semantic agent, which means that the syntactic subject does not actively initiate, or is not actively responsible for, the action of the verb. Similarly, the combination HAVE-to lacks an object and an 'active' subject. It is perhaps no accident that external or event-oriented necessity is often linked in language to impersonal, passive and existential constructions (cf. Payne 2011, Ba 1995, and various reviews in Hansen/de Haan 2009). 
of their forms and functions (e.g. their inability to be used in the past tense, as a participle or infinitive) also contributed to the rise of HAVE-to as a modal semi-auxiliary because of its usefulness as a gap filler.

Finally, in connection with the historical link between impersonal neden and the development of HAVE (nede)-to (if indeed our story is correct), it is perhaps of interest to mention that the present-day semi-modals HAVE-to and NEED, unlike MUST, still share the lack of an authoritative voice (Coates 1983: 56), and when used in the negative they both convey, again unlike MUST, that 'there is no necessity to do something', rather than that 'there $i s$ a necessity to not do something' (ibid.). In addition, the fact that HAVE-to allows "habitual aspect, while MUST does not" (ibid.) is also of interest because it may well be related to the fact that HAVE was also in use as a weak possessive in existential clauses.

\section{The grammaticalization of as good as}

By virtue of their function, Present-day English expressions such as a bit, as good as, far from, more or less or somewhat, can all be classified as degree modifiers. Despite their functional similarity, however, the expressions in question show only partly overlapping grammatical behaviour. (12) below lists and illustrates some of the main grammatical slots in which degree modifiers are found. Focusing by way of example only on the five items listed above, one finds that all five can modify predicative adjectives, as in (i), but only far from, more or less and somewhat can modify attributive adjectives as well, as in (ii). While far from cannot modify finite verb forms, $a$ bit, as good as, more or less and somewhat can, yet they do so occurring in different positions. As good as always precedes the finite (lexical) verb, as in (iii), whereas more or less and somewhat can either precede or follow, as in (iv). Then there is a bit, which can only follow the verb. When modifying a noun phrase, a bit and somewhat are linked to the noun phrase by of, as in (v), unlike far from, more or less and as good as, which directly precede the noun phrase, as in (vi). The differences are summarized in Table 5.

(12) Main grammatical slots for degree modifiers

(i) [is _ ADJ $]$ This wedding of yours is a bit inconvenient for me, actually. (1991, $\mathrm{BNC})$ 
(ii) $\left[a \_\right.$ADJ N] But I think you will also see, sir, as the details unfold, that it is in its nature a far from simple case. (1986, BNC)

(iii) $\left[\mathrm{N} \_\mathrm{V}_{\text {fin }}\right] \mathrm{Oh}$, it's all right, she didn't even hesitate, she as good as popped the question herself. (1993, BNC)

(iv) $\left[\mathrm{N} \mathrm{V}_{\text {fin }}\right]$ Being one-sided, the interest of this correspondence depends somewhat on what one thinks of Maud. (1992, BNC)

(v) [is _ of $a \mathrm{~N}]$ Sorry -- problem's a bit of a silly word to use in the light of what's happened to you. (1991, BNC)

(vi) $\left[i s \_a \mathrm{~N}\right]$ and secondly you presented what the County Councillors do as more or less a rubber stamping of what the officers put before them. (s.d., BNC)

\begin{tabular}{|ll|ccccc|}
\cline { 3 - 7 } \multicolumn{1}{c|}{} & a bit & as good as & far from & more or less & somewhat \\
\hline (i) & is - ADJ & + & + & + & + & + \\
(ii) & $a-$ ADJ N & - & - & + & + & + \\
(iii) & $\mathrm{N}$ - $\mathrm{V}_{\text {fin }}$ & - & + & - & + & + \\
(iv) & $\mathrm{N} \mathrm{V}_{\text {fin }}$ & + & - & - & + & + \\
(v) & is - of a $\mathrm{N}$ & + & - & - & - & + \\
(vi) & is _ a $\mathrm{N}$ & - & + & + & + & - \\
\hline
\end{tabular}

Table 5. Grammatical distribution of five degree modifiers.

If the net is cast wider to include more grammatical contexts and more degree modifiers - say, $a$ lot, any, hardly, kind of, much, pretty, rather, some - differences only accumulate. In fact, on closer inspection, hardly any two degree modifiers can be found that have the same grammatical distribution.

Where, from a synchronic point of view, this situation is something of an embarrassment, a diachronic approach offers some hopes of disentangling the distributional chaos. Some of the differences are explained by the different lexical sources from which degree modifiers developed. Take $a$ bit as an example. A bit started out as a noun that initially meant 'a bite', hence 'a small morsel of food', underwent semantic generalization to indicate any small quantity, and eventually developed (among other things) into a degree modifier marking low degree (Traugott 2008; Claridge \& Kytö 2014). Knowing this, we can account for some of the grammatical behaviour $a$ bit displays as a degree modifier. For instance, that a bit follows rather than precedes the verb it qualifies naturally reflects its use as direct object to transitive verbs when it was still a noun 
phrase - compare (13a-b). In other words, the syntactic versatility of the source item goes some way towards explaining the eventual distributional behaviour of the degree modifier.

(13) a. She worried a bit if he had got back safely, but not enough to ask anyone if he had. (1993, BNC)

b. they looked eagerly at each other, they both changed Countenance, and neither of them offer'd to taste a Bit. (1765-70, CLMET3.0)

There is a complication, however. (12)i above shows that a bit can also premodify predicative adjectives - a position its lexical source could not occupy. Such distributional discrepancies between source item and degree modifier point to historical extensions. Indeed, a bit started regularly appearing with predicative adjectives ${ }^{22}$ well after it had become established as a degree modifier in other contexts - compare (9)-(10) (Claridge \& Kytö 2014: 251).

$$
\text { Ax him some deep question, that he may shew himself a bit. (1779, CLMET3.0) }
$$
and if she is a bit fractious at times, remember what she has gone through. (1848, CLMET3.0)

However, if degree modifiers could extend to new grammatical contexts, they should eventually all end up with very similar, even identical, grammatical distributions. That this is not the case, implies that extension must be constrained. The construction conspiracy hypothesis may be able to account for these constraints.

To illustrate the role of supporting constructions, we consider here in some more detail the history of the degree modifier as good as and contrast it with that of two other degree modifiers, its near-synonym all but and its Dutch cognate zo goed als (all three are what Quirk et al. 1985: 597 call "approximators", meaning 'almost, virtually'). Not only do the three expressions have divergent histories, the emergent differences between them can be linked to distinct (i.e. itemspecific or language-specific) sets of supporting constructions.

\footnotetext{
22 mogelijk gesteund door pronominal quantifier + postnominal adjective (nothing urgent)
} 
From Late Middle English, as good as could be used as a degree modifier, as in (14a) and (14b). ${ }^{23}$ As the examples show, its use was at this point syntactically restricted to modifying predicative adjectives (including secondary predicates) and past participles. It was also collocationally restricted, usually combining with elements that denoted death or destruction. ${ }^{24}$

(14) a. and hys son fell downe be fore hym as good as dede. (1448, IMEPCS)

b. Yerelonde..myghte not be forborne But if Englond were nyghe as gode as lorne. (a1450-1500(1436), MED)

From its use with predicative adjectives and past participles, the degree modifier use of as good as underwent a number of extensions. It came to combine with nouns, as in (15a). Also, it came to combine with more verb forms, starting with active perfect verbs (15b), later with bare infinitives with $d o$-support (15c), bare infinitives with modals (15d), and finally with finite past and present forms (15e-f). Note in these examples also a loosening of the collocational constraints that characterized Middle English usage.

(15) a. Afterward by the [construction?] of the neighbours of the places there aboutes, which [...] builded them houses to dwel among them, at lengthe there was such a resort of men thither, that it was euen as good as a city. (1564, EEBOCorp1.0)

b. Yea excellent, we haue as good as won the wager. (1573, EEBOCorp1.0)

c. And Bellarmine does as good as confesse this one [...]. (1617, EEBOCorp1.0)

\footnotetext{
${ }^{23}$ The history of as good as is described here on the basis of various sources. For Middle English these are IMEPCS and the quotation database of the MED. For Early Modern English, which is when all the relevant extensions take place, use has been made of EEBOCorp1.0 (Petré 2013). EEBOCorp1.0 was compiled from the Early English Books Online archive and contains over half a billion words of running text, covering the period 1480-1700.

${ }^{24}$ The origin of the degree modifier use is not completely clear. It stands to reason that it is historically related to the similative as...as-construction, which grades a property, introduced by the first as, with respect to a reference value, introduced by the second, e.g. I neuer met with no knyght but I was as good as he / or better (1485, IMEPCS). Our Middle English data do not contain bridging contexts that link the similative construction to the degree modifier. Even so, a historical link between the two constructions could explain the negative connotation typical of the degree modifier in its earliest use. The reference value in the similative as...asconstruction is typically treated as a minimal level on a scale that the 'comparisee' either matches or emulates (e.g. he muste proue that hym selfe was prophecyed vppon to be the fore goer of some newe Cryste as good as euer was the olde (1533, EEBOCorp1.0)). In other words, similative as good as tended to imply 'better than'.
} 
d. but he will deale kindly with him, he will as good as give them to him, if he will but make a legge [i.e. 'bow'], and thanke him for them. (1618, EEBOCorp1.0)

e. Neither needs their any proofe; for the common people as good as thought so before (1638, EEBOCorp1.0)

f. for he as good as confesseth that we are bound to [...] (1641, EEBOCorp1.0)

The historical extensions seen in as good as only partly resemble those of its nearsynonym all but. As described in De Smet (2012), all but developed into a degree modifier with nouns in the late eighteenth century. ${ }^{25}$ By the early nineteenth century it could be found appearing with nouns (16a), predicative adjectives (16b), past participles (16c) and perfect verb forms (16d).

(16) a. he considered it all but a just punishment for their attempted mesalliance. (1834, COHA)

b. as if the works of nature were not all but infinite (1821, COHA)

c. The Morea, in 1775, was all but desolated, by letting loose upon it twentyfive thousand Albanians, after its desertion by the Russians (1827, COHA)

d. even in the very instant it appeared within his gripe, he had all but clutched it, when his wife [...] hastily stepped forward (1827, COHA)

That much is familiar, yet two differences with as good as stand out. First, all but also extended to attributive adjectives (17a). Second, all but appeared with past and present tense verb forms $(17 b-c)$ before it started combining with bare infinitives (17d).

(17) a. and the celestial spaces are continually strewed with this highly rarified, and all but immaterial substance (1836, COHA)

b. $\quad$ true, she all but consented -- and did consent in a sort (1835, COHA)

\footnotetext{
25 The history of all but is here described on the basis of the data set used by De Smet (2012), drawn from COHA (Davies 2011). COHA is at present the richest data source for 19th and 20th century English, but only poorly represents the very first decades of the nineteenth century and contains no data predating 1810 . This makes it difficult to establish the exact order of events before 1830.
} 
c. he turns his head and gives me a look that all but says, How d'ye do, Will? (1836, COHA)

d. an occasional squall of sleet or snow would all but congeal his very eyelashes together. (1851, COHA)

How to account for the extensions in as good as and all but? Figure 1 proposes diachronic trajectories of extension for the two degree modifiers that are consistent with the available data. ${ }^{26}$ Importantly, both trajectories consist exclusively of extensions between contexts sharing some formal or syntactic element. The similarities include the following: (i) nouns and adjectives can both occur in predicative position following copular be; (ii) adjectives and past participles are near-perfect paradigmatic alternates; (iii) past participles occur in predicative copular constructions as well as in the perfect tense; (iv) most past tense finite forms are phonologically identical to the past participle; (v) past tenses and present tenses are paradigmatic alternates, as are affirmative $d o$-support constructions, (vii) which in turn resemble modal constructions in taking a bare infinitive. It can be argued, then, that every step in the extension process draws on similarities to established use. Put differently, every grammatical context to which a degree modifier spreads can become a 'supporting construction' for the following extension.

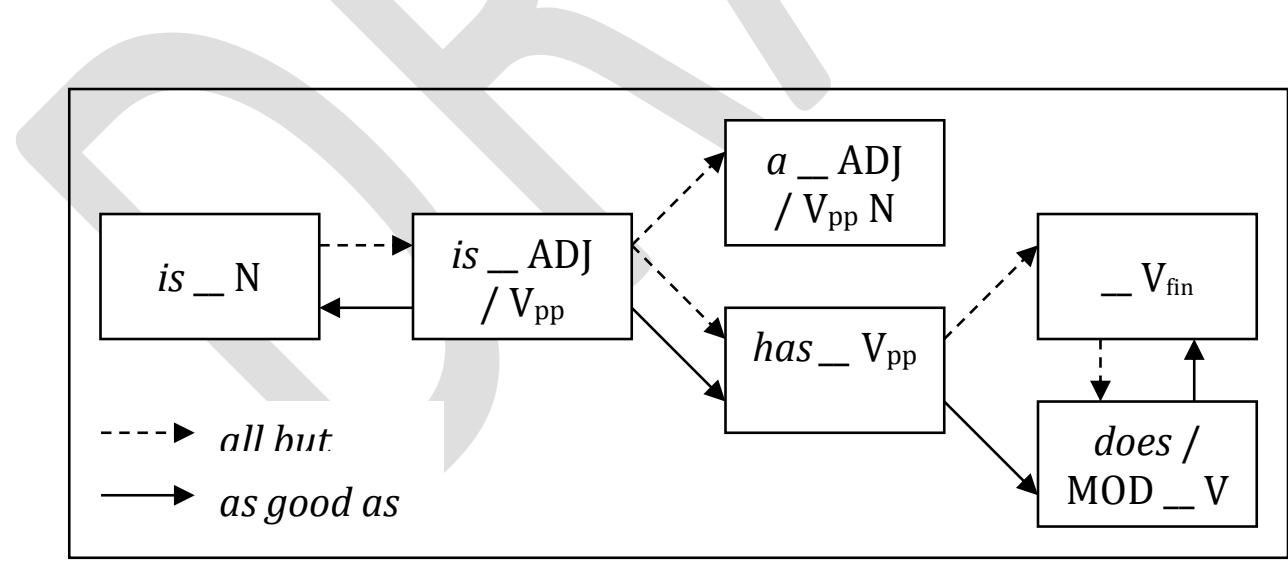

Figure 1. Diachronic trajectories of extension in as good as and all but.

\footnotetext{
${ }^{26}$ For as good as the trajectory in Figure 1 is based on first attestations (as provided above). For all but, whose earliest history is less well documented, the trajectory is partly based on first attestations and partly inferred from the timing and pace of subsequent increases in usage frequencies (see De Smet 2012).
} 
However, this cannot suffice to explain the divergences between as good as and all but. To account for these we must take into account the broader constructional networks in which each item features. For a start, why did as good as extend to do-support and modal constructions before it appeared with finite verb forms, whereas all but took the opposite trajectory? There is evidence to suggest that, for as good as, extension to do-support contexts just happened to be supported by a range of additional patterns - all related to the degree modifier by more or less incidental lexical and syntactic correspondences. First, there was adverbial as good, meaning 'to the same effect'. The pattern had derived from a construction that had a bare or to-infinitive as postposed subject and an optional dative benefactive, as in (18a). It survived into Early Modern English, now with the benefactive reinterpreted as subject, but still with a bare or to-infinitive, as in $(18 b)$.

(18) a. A man were as good to be dede As smell therof the stynk. (c1500, MED)

b. we had as good loose somewhat, as vndoe our selues by law, and then loose that too. (1615, EEBOCorp1.0)

Second, there was as much as, which could appear in the sequence do as much as $\mathrm{V}$, where much and the bare infinitive jointly functioned as direct object to transitive $d o$, integrated by the similative as... as construction. The use is illustrated in (19).

for he that amid pleasant discourses and mery talke mooveth a speech that causeth bending and knitting of browes [...], he doth as much as overcast faire weather with a blacke and darke cloud (1603, EEBOCorp1.0)

Third, do already frequently combined with good in the expression do good, as in (20), where good was presumably a noun and the object of transitive $d o$.

one moment in hell will bee worse then all the pleasure in the world did good (1630, EEBOCorp1.0) 
All these were supporting constructions that could facilitate the extension of as good as into dosupport contexts. For lack of formal similarities, none of these supporting constructions were available to all but, whose trajectory of extension consequently took another course.

The other discrepancy between as good as and all but is harder to explain. Why did all but extend to attributive adjectives, while as good as never did? A (tentative) argument can be made, again relying on supporting constructions. All (as a quantifier) had always been felicitous as the first element of a noun phrase, and (as an intensifier) it could even occur following determiners, as in (21a). But could already precede attributive adjectives, as in (21b).

(21) a. It is an all potent restorative -- a sovereign antidote against the blue devils, and an infallible driver out of black ones. (1811, COHA)

b. on the 28th of June [they] came in sight of the town of Apalache, of which they took possession with but slight opposition. (1821, COHA)

Even the surface sequence all but ADJ $\mathrm{N}$ occurred regularly. Typically, this was with all functioning as quantifying pronoun, and but as preposition introducing a dependent noun phrase, but just occasionally, a single context would allow both the pronoun-cum-preposition reading and the degree modifier reading, as in (22-ab).

(22) a. the King's intention appeared to be a pardon to all but actual regicides (1753, CLMET3.0)

b. After having endured all but real suffocation for above a quarter of an hour in the tub, I was moved to the bed and wrapped in blankets. (1771, CLMET3.0)

If only through homophony, all these patterns could predispose degree modifier all but to extend into attributive adjective contexts. In contrast, they would not have borne on the development of as good as. Regarding the latter, the speaker of English who wanted to use as good as with a nominal attribute may have been inclined to another solution, since as good as would appear modifying postposed adjectives, as in (23a). Here we can suspect another supporting construction, seeing that similative as could easily introduce postmodifiers, as in (23b). 
(23) a. the Turks [... disdained] that they [...] should be so derided of a handfull of men $a s$ good as alreadie vanquished [...]. (1603, EEBOCorp1.0)

b. O blessed Virgin, deliuer me out of this danger, and $\mathbf{J}$ will offer vnto thee [...] a candle as bigge as the maine maste of my ship. (1609, EEBOCorp1.0)

Where as good as and all but diverged because of differences in very local, item-specific constructional networks, divergences between as good as and its Dutch cognate zo goed als arose because of structural differences between the grammars of English and Dutch. Zo goed als started out as a degree modifier in the same grammatical contexts as as good as - i.e. with predicative adjectives, such as the secondary predicate in (24a), and with predicative past participles, as in $(24 b) .{ }^{27}$ But from there the items entered different trajectories of extension.

(24) a. Hy beloofd [...] het aldus... zo goedals splinternieuw voor den dag he promises it this way as good as brand-new to the day te doen komen (1731, WNT)

to make come

'This way he promises to make it appear as good as brand-new.'

b. Uwen Horatius, die ik, al eenigen tijd geleden, getoond heb your Horace which I already some time ago shown have dat zo goed als uitverkocht is [...] (1738, WNT) that as good as sold-out is

'Your Horace, which I have some time ago shown to be as good as sold out ...'

Let us consider two areas of divergence, both showing how innovation is steered by existing synchronic structures. First, attributive adjectives and past participles can take much more elaborate premodification in Dutch than in English (which has to resort to postmodification to allow for the same complexity), as in (25a). This explains why zo goed als, unlike as good as, but like any other Dutch degree modifier, easily spread from predicative into attributive contexts, as in (25b).

\footnotetext{
27 The history of zo goed als is here described on the basis of the WNT quotation database, the self-compiled CHK (a newspaper corpus of 18th and 19th century Dutch based on the Historische Kranten Online archive), and the TNC (another large newspaper corpus covering Present-day Dutch).
} 
(25)

a. de in het openbaar afgelegde verklaringen (2002, TNC)
the in public $\quad$ made statements

'the statements made in public'

b. de vrijverklaring der toch zoo goed als verlorene Amerika[an]sche

the release of the anyway as good as lost American

bezittingen (1824, CHK)

possessions

'the release of the American possessions that had been as good as lost anyway'

Second, Dutch has a large class of 'separable' verbs whose first element will appear preceding the verbal stem in most contexts, including with past participles, but takes clause-final position in main clauses when the verb is finite. Vaststellen 'fix, arrange' is such a verb, consisting of a separable element vast 'fast/firm' and a verbal stem stellen 'put'. In (26a) vast and stellen appear as a single complex word, while in (26b) they behave as two separate words.

a. over een periode die in overleg wordt vastgesteld (2002, TNC)
during a term that in consultation is fast-put
'for the duration of a term that is fixed by mutual agreement'
b. Het akkoord stelt de voorwaarden vast waarop [...]. (2002, TNC)
the agreement puts the conditions fast on which...
'The agreement fixes the conditions on which...'

In the development of zo goed als, these separable verbs acted as a bridge between adjective modification and verb modification. When zo goed als appeared with past participles, it also appeared with the past participles of separable verbs, as in (27a). Next, zo goed als began to appear with finite forms of separable verbs. The extension was facilitated by the resemblance of the separable first elements to secondary predicates - indeed, zo goed als simply continues to precede the separable element whenever it takes clause-final position, as in (27b) (conveniently avoiding violation of the $\mathrm{V}_{2}$ rule in Dutch main clauses). Later still, zo goed als appeared with other types 
of complex predicates, whose positional behavior is the same as that of separable verbs, as in (27c).

(27) a. Men meld [...] dat de Huwelyks Verbintenis van een Noordschen one reports that the wedding of a Northern

Prins met een Nabuurige Princes tegenwoordig zo goed als vastgesteld prince with a neighbouring princess presently as good as fixed is is $(1765, \mathrm{CHK})$

'It is reported that the wedding of a Northern prince with a neighbouring princess has been as good as fixed.'

b. Vermits men geene Matroozen voor de Koopvaardy Scheepen kan because one no sailors for the merchant ships can krygen [...], staat de Koophandel zoo goed als stil (1777, CHK) get stands the commerce as good as still

'Because no sailors can be found for the merchant ships, commerce has virtually come to a standstill.'

c. [...] geloof ik, dat wij den opstand zoo goed als meester zijn. believe I that we the uprising as good as master are (1826, CHK)

'I believe we have the uprising almost under control.'

The expected final step is extension to simple finite verbs. However, in Present-day Dutch, zo goed als is still only marginally acceptable with simple finite verbs, and only so in subordinate clauses, as in (28a) - as opposed to (28b). In comparison to English as good as, the restriction to subordinate clauses looks bizarre. The reason is the regularities emergent from prior established patterns, which dictate that zo goed als must follow the finite verb in main clauses, but should always precede at least part of the predicate in its scope, exactly as in (42)-(44) above.

(28) a. Deze boeren veranderden zoveel aan het slot dat het zijn These farmers changed so much to the castle that it its 
karakter als herenhuis zo goed als verloor (s.d., Google)

character as manor house as good as lost

'These farmers made so many changes to the castle that it as good as lost its original character as a manor house.'

b. Het slot (*zo goedals) verloor (*zo goedals) zijn karakter als

the castle (as good as) lost (as good as) its character as

herenhuis (*zo goed als).

manor house (as good as)

'The castle as good as lost its original character as manor house.'

It appears, then, that Dutch zo goed als finally ran out of luck - or rather, out of supporting constructions.

\section{Conclusions}

The critique often levelled against analogy - that analogy is too unconstrained and too unpredictable to have any true explanative power - can at least in part be countered by studying changes within their broader synchronic context. The two case studies presented above show that the timing and context of analogical change is not random, but is determined by the synchronic state of the grammatical system of a given language at a given time. In each case, the timing and/or contexts of change can be linked to the absence or availability of constructions, both substantive and structural, on which an innovation can be modeled. For HAVEto decisive factors of change included (among others) chunking of HAVE and to in Middle English, the rise of the to-infinitive, particularly with verbs expressing modal notions, and complex interactions between HAVE-to and the verb and adverb nede(n). For as good as, analogical extension has been shown to be to some extent a self-feeding process, with one extension facilitating the next. But the process was also steered by the synchronic availability of various supporting constructions.

The notion of 'supporting construction' (Abbot-Smith \& Behrens 2006) allows a more explicit operationalization of analogy. Its transfer from language acquisition to language change appears basically unproblematic, bearing in mind various differences in how the effect of supporting constructions can be expected to play out in the two domains (as discussed above). The 
notion does raise new issues, however. For one thing, supporting constructions potentially range from fully substantial chunks to highly abstract patterns. Not only may the respective impact of either type of supporting construction vary between acquisition and change, it is also conceivable that different types of supporting constructions bear differently on change as such. For instance, it is striking that analogical change proceeds faster in the case of as good as than in the case of HAVE-to. Perhaps this is because the supporting constructions involved are all highly substantial in the former case but more mixed in the latter.

Another question - also raised by Abbot-Smith \& Behrens (2006) - is whether existing constructions can also negatively impact on potential changes. As argued above, Abbot-Smith \& Behrens (2006) argumentation on this point transfers less easily to diachrony. In the history of $a s$ good as there is no hint of hindrance from other constructions: synonymy is perfectly tolerated witness the later emergence of all but. In the case of HAVE-to, the situation is more complex, since part of the success of HAVE-to can be linked to the decline of impersonal need - which could be interpreted to mean that need hindered HAVE-to until it declined. In general, modal verbs, constituting a closed class, might be less tolerant of synonymy than degree modifiers, forming an open class.

\section{References}

Abbot-Smith, K. F. \& H. Behrens. 2006. How known constructions influence the acquisition of other constructions: the German passive and future constructions. Cognitive Science 30: 9951026.

Anttila, R. 2003. Analogy: The Warp and Woof of Cognition, in B. D. Joseph and R. D. Janda (eds), The Handbook of Historical Linguistics. Oxford: Blackwell, 425-40.

Ba, E.L. 1995. The obligation modality in Western Nilotic languages. In J. Bybee and S. Fleischman (eds) Modality in Grammar and Discourse. Amsterdam: Benjamins. 107-133.

Barðdal, Jóhanna (2008) Productivity: Evidence from Case and Argument Structure in Icelandic. Amsterdam: Benjamins.

Behrens, H. 2009. Usage-based and emergentist approaches to language acquisition. Linguistics 47: 383-411.

Bod, R. 2009. From exemplar to grammar. A probabilistic analogy-based model of language learning. Cognitive Science 33: 752-793. 
Bod, R. Hay, J. and Jannedy, S. (2003) (eds) Probabilistic Lingusitics. Cambridge Mass.: MIT Press.

Brinton, L. J. 1991. The origin and development of quasimodal have to in English, Paper presented to the 10th ICHL, Amsterdam 1991. Unpublished manuscript (http://faculty.arts.ubc.ca/lbrinton/HAVETO.PDF)

Bybee, J. 2010. Language, Usage and Cognition.Cambridge: Cambridge University Press.

Bybee, J. and Beckner, C. 2015. Language use, cognitive processes and linguistic change. In C. Bowern and B. Evans (eds) The Routledge Handbook of Historical Linguistics. London: Routledge. 503-518.

Chalmers, D.J., French, R.M. and Hofstadter, D.R. 1992. High-level perception, representation, and analogy: A critique of artificial intelligence methodology, Journal of Experimental and Theoretical Artificial Intelligence 4: 185-211. [available on http://consc.net/papers/highlevel.pdf]

Claridge, C. and Kytö, M. 2014. 'You are a bit of a sneak': Exploring a degree modifier in the Old Bailey Corpus, in M. Hundt (ed.), Late Modern English Syntax. Cambridge: Cambridge University Press, 239-268.

Coates, J. 1983. The Semantics of the Modal Auxiliaries. London: Croom Helm.

Croft, William (2001) Radical Construction Grammar. Oxford: Oxford University Press

Deacon, T.W. 1997. The Symbolic Species. The Co-Evolution of Language and the Brain. New York: Norton.

Deacon, T. W. (2003). Universal Grammar and Semiotic Constraints, in M. H. Christiansen and S. Kirby (eds), Language Evolution. Oxford: Oxford University Press, 111-39.

De Smet, H. 2009. Analyzing reanalysis. Lingua 119: 1728-1755.

De Smet, H. 2012. The course of actualization. Language 88: 601-633.

Ekwall, Eilert 1965 [1975]. A History of Modern English Sounds and Morphology (translated and edited by Alan Ward). Oxford: Blackwell.

Fischer, O. 1994. The development of quasi-auxiliaries in English and changes in word order. Neophilologus 78: 137-164.

Fischer, O. 2011. Grammaticalization as analogically driven change?. In Narrog and Heine (eds), $31-42$. 
Fischer, Olga. 2015. The influence of the grammatical system and analogy in processes of language change: The case of the auxiliation of have to once again.In XX etc

Fischer, Olga and Hella Olbertz. (in prep.). The role played by analogy in processes of language change: The case of English have to compared to Spanish tener que

Fleischman, S. 1982. The Future in Thought and Language: Diachronic Evidence from Romance. Cambridge: Cambridge University Press.

Gentner, D. 2003. Why We're So Smart, in D.Gentner and S. Goldin-Meadow (eds), Language in Mind. Advances in the Study of Language and Thought. Cambridge Mass.: MIT Press, 195235.

Gentner, D. 2010. Bootstrapping the mind: Analogical processes and symbol systems, Cognitive Science 34: 752-775.

Gentner, D., Anggoro, F.K. and Klibanoff, R.S. 2011. Structure mapping and relational language support children's learning of relational categories, Child Development 82: 1173-1188.

Gentner, D., Holyoak, K.J and Kokinov, B.K. (eds) 2001. The Analogical Mind. Perspectives from Cognitive Science. Cambridge Mass: MIT Press.

Gentner, D. and Namy L.L. 2006. Analogical processes in language learning, Current Directions in Psychological Science 15: 297-301

Gentner, D. and Smith, L. 2012. Analogical reasoning, in V.S. Ramachandran (ed.) Encyclopedia of Human Behavior ( $2^{\text {nd }}$ ed.). Oxford: Elsevier, 130-136.

Goldberg, A. E. 1995. Constructions: A Construction Grammar Approach to Argument Structure. Chicago: The University of Chicago Press.

Goldberg, Adele E. 2006. Constructions at Work. The Nature of Generalization in Language. Oxford: Oxford University Press.

Goldwater M.B., Tomlinson M.T., Echols C.H., Love B.C. (2011). Structural priming as structure-mapping: children use analogies from previous utterances to guide sentence production. Cognitive Science.35:156-70.

Hansen, B and de Haan, F. 2009. Modals in the Languages of Europe. Berlin: Mouton de Gruyter.

Hawkins, J. A. 2004. Efficiency and Complexity in Grammars. Oxford: Oxford University Press. Heine, B. 1993. Auxiliaries. Cognitive Forces and Grammaticalization. Oxford: Oxford University Press. 
Heine, Bernd. 2014. Grammaticalization, metaphor, and explanation: What accounts for unidirectionality? Plenary paper presented at the Workshop de Gramaticalização II,

Universidade Federal Fluminense, Niterói, 7 May, 2014 (http://www.workshop gramaticalizacao.uff.br/images/Rio.pdf)

Hofstadter, D. 1995. Fluid Concepts and Creative Analogies. Computer Models of the Fundamental Mechanisms of Thought. New York: Basic Books.

Hollmann, Willem B. 2003. Synchrony and diachrony of English periphrastic causatives: a cognitive perspective. Ph.D. dissertation. Manchester: University of Manchester. [http://www.lancaster.ac.uk/staff/hollmann/WBH_PhD_causatives.pdf]

Holyoak, K. J. and Thagard, P. (1995). Mental Leaps. Analogy in Creative Thought. Cambridge Mass.: MIT Press.

Hogg, Richard M. 1988. Snuck: The development of irregular preterite forms, in G. Nixon and J. Honey (eds), An Historic Tongue. Studies in English Linguistics in Memory of Barbara Strang. London: Routledge, 31-40.

Hopper, P. J. and Thompson, S. A. 1980. Transitivity in Grammar and Discourse. Language 56: 251-99.

Itkonen, E. 2005. Analogy as Structure and Process. Amsterdam: Benjamins.

Krug, M. G. 2000. Emerging English Modals: A Corpus-Based Study of Grammaticalization. Berlin: Mouton de Gruyter.

Kuryłowicz, Jerzy. (1949). La nature des procès dits “analogiques”. Acta Linguistica 5: 15-37.

Los, B. 2005. The Rise of the to-Infinitive. Oxford: Oxford University Press.

Łęcki, A.M. 2010. Grammaticalisation Paths of Have in English. Bern: Peter Lang

Manabe, K. 1989. The Syntactic and Stylistic Development of the Infinitive in Middle English. Fukuoka: Kyushu University Press.

Mańczak, Witold. 1958. Tendences générales des changements analogiques. Lingua 7: 298-325; 387-420.

Meurman-Solin, A., López-Couso, M.J., and Los, B. 2012. (eds). Information Structure and Syntactic Change in the History of English. Oxford: Oxford University Press.

Narrog, H. 2005. Modality, mood, and change of modal meanings: A new perspective. Cognitive Linguistics 16: 677-731. 
Narrog, H. and Heine, B. 20111. (eds), The Oxford Handbook of Grammaticalization. Oxford: Oxford University Press.

Noël, D. 2012. Grammaticalization in diachronic construction grammar. Lecture held at the Universidade Federal do Rio Grande do Norte, Natal, Brasil, November 27, 2012

Nöth, W. 2001. Semiotic foundations of iconicity in language and literature. In O. Fischer and M. Nänny (eds), The Motivated Sign. Amstredam: Benjamins, 17-28.

Payne, D.L. 2011. The Maa (Eastern Nilotic) impersonal construction. In A. Malchukov and A. Siewierska (eds) Impersonal Constructions. A Cross-Linguistic Perspective. Amsterdam: Benjamins, 257-284.

Paul, H. 1909, $4^{\text {th }}$ ed.[1886]) Prinzipien der Sprachgeschichte. Halle: Niemeyer.

Quirk, R., Greenbauw, S., Leech, G. and Svartvik, J. 1985. A comprehensive grammar of the English language. London: Longman.

Slobin, D.I. (ed.). 1985. The Crosslinguistic Study of Language Acquisition. Vol. 2. Theoretical Issues. Mahwah N.J.: Erlbaum Associates.

Tomasello, M. 2003. Constructing a Language. A Usage-Based Theory of Language Acquisition. Cambridge Mass.: Harvard University Press.

Traugott, E.C. 2008. The grammaticalization of NP of NP patterns. In A. Bergs \& G. Diewald (Eds.). Constructions and language change. Berlin: Mouton de Gruyter, 23-45.

Traugott, E. C. 2011. Grammaticalization and mechanisms of change. In Narrogand Heine, (eds), 19-30.

Van Steenis, Lindsey. 2013. The grammaticalization of have to and hebben te: A comparative study between English and Dutch. MA thesis, Faculty of Humanities, University of Amsterdam.

Yanovich, I. 2013. Four Pieces for modality, context and usage. PhD Thesis, MIT, Cambridge Mass. 